\title{
Pridopidine selectively occupies sigma-1 rather than dopamine D2 receptors at behaviorally active doses
}

\author{
Kristoffer Sahlholm ${ }^{1,3}$ - Jurgen W. A. Sijbesma ${ }^{1} \cdot$ Bram Maas $^{1} \cdot$ Chantal Kwizera $^{1}$ • \\ Daniel Marcellino $^{2}$ • Nisha K. Ramakrishnan ${ }^{1}$ • Rudi A. J. O. Dierckx ${ }^{1}$ • \\ Philip H. Elsinga ${ }^{1}$ - Aren van Waarde ${ }^{1}$
}

Received: 6 May 2015 / Accepted: 15 June 2015 /Published online: 11 July 2015

(C) The Author(s) 2015. This article is published with open access at Springerlink.com

\begin{abstract}
Rationale Dopamine stabilizers have stimulatory actions under low dopamine tone and inhibitory actions under high dopamine tone without eliciting catalepsy. These compounds are dopamine $D_{2}$ receptor $\left(D_{2} R\right)$ antagonists or weak partial agonists and may have pro-mnemonic and neuroprotective effects. The mechanism underlying their stimulatory and neuroprotective actions is unknown but could involve sigma-1R binding.

Objectives The present study examined sigma- $1 \mathrm{R}$ and $\mathrm{D}_{2} \mathrm{R}$ occupancy by the dopamine stabilizer pridopidine (ACR16) at behaviorally relevant doses in living rats.

Methods Rats were administered 3 or $15 \mathrm{mg} / \mathrm{kg}$ pridopidine, or saline, before injection of the radiotracer ${ }^{11} \mathrm{C}-\mathrm{SA} 4503$ (sigma-1R) or ${ }^{11} \mathrm{C}$-raclopride $\left(\mathrm{D}_{2} \mathrm{R}\right)$. Some animals received $60 \mathrm{mg} / \mathrm{kg}$ pridopidine and were only scanned with ${ }^{11} \mathrm{C}$ raclopride. Cerebral ${ }^{11} \mathrm{C}$-SA4503 binding was quantified using metabolite-corrected plasma input data and distribution volume $\left(V_{\mathrm{T}}\right)$ calculated by Logan graphical analysis. ${ }^{11} \mathrm{C}$ raclopride binding was quantified using striatum-tocerebellum ratios and binding potentials calculated with a simplified reference tissue model.
\end{abstract}

Aren van Waarde

a.van.waarde@umcg.nl

1 Department of Nuclear Medicine and Molecular Imaging, University Medical Center Groningen, University of Groningen, Groningen, The Netherlands

2 Department of Physiology and Institute of Biomedical Technology (ITB), Center for Biomedical Research of the Canary Islands (CIBICAN), University of La Laguna School of Medicine, Tenerife, Spain

3 Present address: Department of Neuroscience, Karolinska Institutet, 17177 Stockholm, Sweden
Results Cunningham-Lassen plots indicated sigma-1R occupancies of $57 \pm 2$ and $85 \pm 2 \%$ after pretreatment of animals with 3 and $15 \mathrm{mg} / \mathrm{kg}$ pridopidine. A significant (44-66\%) reduction of ${ }^{11} \mathrm{C}$-raclopride binding was only observed at $60 \mathrm{mg} / \mathrm{kg}$ pridopidine.

Conclusions At doses shown to elicit neurochemical and behavioral effects, pridopidine occupied a large fraction of sigma-1Rs and a negligible fraction of $\mathrm{D}_{2}$ Rs. Significant $D_{2} R$ occupancy was only observed at a dose 20 -fold higher than was required for sigma-1R occupancy. The characteristics of dopamine stabilizers may result from the combination of high sigma- $1 \mathrm{R}$ and low $\mathrm{D}_{2} \mathrm{R}$ affinity.

Keywords MicroPET $\cdot$ Kinetic analysis $\cdot{ }^{11} \mathrm{C}-\mathrm{SA} 4503$.

${ }^{11} \mathrm{C}$-raclopride $\cdot$ Receptor occupancy

\section{Introduction}

Pridopidine (also known as ACR16 or Huntexil) is a phenylpiperidine compound undergoing clinical trials for treatment of motor symptoms in Huntington's disease (de Yebenes et al. 2011; Kieburtz et al. 2013; for the ongoing Pride-HD trial, see NCT02006472 at clinicaltrials.gov). Moreover, pridopidine has shown promising results in limited trials for schizophrenia and Parkinson's disease (Ponten et al. 2010). The drug displays micromolar affinity for the dopamine $D_{2}$ receptor $\left(D_{2} R\right)$, where it acts as an antagonist (Dyhring et al. 2010; Sahlholm et al. 2014) or very weak partial agonist (Seeman et al. 2009; Kara et al. 2010). Pridopidine antagonizes amphetamine-induced hyperlocomotion (Natesan et al. 2006; Ponten et al. 2010) and reduces L-DOPA-induced locomotor sensitization in 6hydroxydopamine-lesioned rats (Ponten et al. 2013). However, even at doses resulting in near-complete $\mathrm{D}_{2} \mathrm{R}$ occupancy 
(assessed using ex vivo radioligand binding), pridopidine shows very low propensity for inducing catalepsy (Natesan et al. 2006). Furthermore, pridopidine stimulates locomotor activity in habituated animals showing low baseline locomotor activity (Rung et al. 2008) and increases dopamine release in several brain regions including the prefrontal cortex (Ponten et al. 2010). Based on these properties, pridopidine and structurally related compounds showing similar in vivo efficacy such as (-)-OSU6162 have been termed "dopamine stabilizers" as they exhibit inhibitory or stimulatory effects on dopamine-dependent behavior depending on the prevailing dopamine tone (Ponten et al. 2010).

$(-)$-OSU6162 displays higher in vitro affinity for $\mathrm{D}_{2} \mathrm{R}$ than pridopidine (Pettersson et al. 2010). Interestingly however, while (-)-OSU6162 was more potent in raising serum prolactin and in producing $\mathrm{D}_{2} \mathrm{R}$ occupancy, pridopidine was more potent in inhibiting amphetamine-induced hyperlocomotion (Natesan et al. 2006). Moreover, pridopidine showed procognitive and pro-social effects, which are not typical of $\mathrm{D}_{2} \mathrm{R}$ ligands, in animal models of cognitive and negative symptoms of schizophrenia and in scopolamine-induced amnesia (Rung et al. 2005; Nilsson and Carlsson 2013). Furthermore, the abilities of haloperidol and (-)-OSU6162 to counteract amphetamine-induced hyperlocomotion were abolished in $\mathrm{D}_{2} \mathrm{R}$ knockout mice, whereas the effects of pridopidine persisted (Svensson et al. 2009). Based on the induction of the immediate-early gene Arc (a marker of synaptic activity) by pridopidine in prefrontal cortex, which again is not observed with other $\mathrm{D}_{2} \mathrm{R}$ antagonists or agonists, nondopaminergic effects of pridopidine have been postulated, which would involve an increase in cortical $N$-methyl-D-aspartate (NMDA) receptor activity (Ponten et al. 2010; Waters et al. 2014). Finally, neuroprotective effects of pridopidine and $(-)$-OSU6162 have recently been described in in vitro and in vivo models of Huntington's disease (Ruiz et al. 2012; DiPardo et al. 2013). Taken together, the present literature findings suggest additional sites of action for pridopidine besides $\mathrm{D}_{2} \mathrm{R}$, and as detailed below, we have considered the sigma-1 receptor (sigma-1R) as such an additional target.

The sigma- $1 \mathrm{R}$ is a two-transmembrane protein that is widely expressed in the brain and has been implicated mainly in regulation of synaptic strength and cell survival. Sigma-1R lacks homology to any known mammalian protein, is believed to function both as an ER chaperone and as a co-receptor for a variety of other transmembrane proteins, and has been shown to modulate voltage-gated ion channels, NMDA receptors, and dopamine receptors (Maurice and Su 2009; Navarro et al. 2010; van Waarde et al. 2011). The sigma-1R is known to bind the endogenous steroids dehydroepiandrosteronesulfate and progesterone and the hallucinogenic trace amine, $\mathrm{N}, \mathrm{N}$-dimethyltryptamine, along with exogenous substances such as cocaine and haloperidol (Fontanilla et al. 2009). On basis of the actions of its ligands in animal models, sigma-1R is considered as a pharmacological target for the treatment of Parkinson's disease (including L-DOPA-induced dyskinesia), Alzheimer's disease, schizophrenia, and drug addiction (Guitart et al. 2004; Maurice and Su 2009; van Waarde et al. 2011).

In radioligand competition experiments using ${ }^{3} \mathrm{H}-(+)$-pentazocine, pridopidine and (-)-OSU6162 were recently found to display nanomolar affinity for the sigma-1R (Sahlholm et al. 2013). For pridopidine, the observed affinity for sigma$1 \mathrm{R}$ was about 100 -fold higher than that reported for $\mathrm{D}_{2} \mathrm{R}$ (high-affinity $K_{\mathrm{i}}$ about $70 \mathrm{nM}$ at sigma-1R and $7520 \mathrm{nM}$ at $\mathrm{D}_{2} \mathrm{R}$ ), while (-)-OSU6162 showed only about two times higher affinity for sigma-1R than for $\mathrm{D}_{2} \mathrm{R}$ (high-affinity $K_{\mathrm{i}}$ about $360 \mathrm{nM}$ at sigma-1R and $760 \mathrm{nM}$ at $\mathrm{D}_{2} \mathrm{R}$; Sahlholm et al. 2013; Pettersson et al. 2010). As detailed above, the effects of some sigma-1R ligands are similar to the actions of dopamine stabilizers that cannot easily be attributed to $\mathrm{D}_{2} \mathrm{R}$ antagonism. Therefore, we examined the occupancies of sigma- $1 \mathrm{R}$ and $\mathrm{D}_{2} \mathrm{R}$ by pridopidine in the living rat brain. Pridopidine was administered at the lower end of the active dose range, as determined in previous behavioral and neurochemical studies, in order to assess a putative selective occupancy of sigma-1R at these doses.

\section{Materials and methods}

\section{Radioligands and drugs}

The $\mathrm{D}_{2} \mathrm{R}$ ligand ${ }^{11} \mathrm{C}$-raclopride was prepared by ${ }^{11} \mathrm{C}$-methylation of its hydroxy precursor (Farde et al. 1988). The tracer was dissolved in sterile saline. Specific radioactivity was $>10 \mathrm{GBq} / \mu \mathrm{mol}$ at the time of injection. The sigma-R ligand $1-[2-(3,4-\mathrm{d}$ i m e th ox y p he ne th y 1$)]-4-(3-$ phenylpropyl)piperazine $\left({ }^{11} \mathrm{C}\right.$-SA4503) was produced by ${ }^{11} \mathrm{C}$ methylation of 4-O-demethyl SA4503 (Kawamura et al. 2003). The isotonic tracer solution had a $\mathrm{pH}$ of 6.0 to 7.0 , a specific radioactivity $>15 \mathrm{GBq} / \mu \mathrm{mol}$ at the moment of injection, and a radiochemical purity $>98 \%$. Pridopidine hydrochloride (ACR16) was custom synthesized by Axon MedChem BV (Groningen, Netherlands). HPLC grade ethanol was from Merck (Darmstadt, Germany), and methanol and acetonitrile were purchased from Rathburn (Walkerburn, Scotland).

\section{Animals}

Male Wistar Unilever rats were obtained from Harlan (Boxmeer, Netherlands). The animals were housed in Makrolon cages on a layer of wood shavings at constant temperature $\left(21 \pm 2{ }^{\circ} \mathrm{C}\right)$ and a 12 -to- $12 \mathrm{~h}$ light-dark regimen. They were fed standard laboratory chow (RMH-B, Hope Farms, The Netherlands) and received food and water ad libitum. 
The rats were allowed to acclimate for at least 7 days after they had been transported to Groningen. The research protocol was approved by the Institutional Animal Care and Use Committee of Groningen University (file no. 6867A). All experiments were performed by licensed investigators in compliance with the Law on Animal Experiments of The Netherlands.

\section{Drug dosing and blood sampling}

Saline or pridopidine dissolved in saline $(3,15$, or $60 \mathrm{mg} / \mathrm{kg}$, s.c.) was administered to awake rats $60 \mathrm{~min}$ before tracer injection. Data of the animals (body weight, injected tracer dose, number of subjects in each dose group) are listed in Table 1. Animals were first scanned with ${ }^{11} \mathrm{C}$-raclopride and subsequently with ${ }^{11} \mathrm{C}$-SA4503, after an interval of at least 1 week, with exception of the animals that received $60 \mathrm{mg} / \mathrm{kg}$ pridopidine. Because of limited availability of the test drug, the $60 \mathrm{mg} / \mathrm{kg}$ dose group was scanned only with ${ }^{11} \mathrm{C}$ raclopride.

After drug administration and about 20 min before each microPET scan, animals were anesthetized with isoflurane (Pharmachemie BV, Haarlem, Netherlands). A tail vein cannula was placed in each rat for injection of ${ }^{11} \mathrm{C}$-raclopride and a femoral vein cannula for injection of ${ }^{11} \mathrm{C}-\mathrm{SA} 4503$. In the case of ${ }^{11} \mathrm{C}-\mathrm{SA} 4503$ scans, a femoral artery cannula was also placed for blood sampling and determination of the time course of radioactivity in plasma, as described previously (Ramakrishnan et al. 2014). Both tracers were injected as a slow bolus ( $1 \mathrm{ml}$ of saline-diluted tracer solution infused during a period of $1 \mathrm{~min}$ ), using a Harvard-style injection pump. By the use of a pump, inter-individual variability in the outcome parameters of kinetic modeling is reduced (Visser et al. 2013).

From each animal used for kinetic modeling (Table 1), 15 arterial blood samples (volume 0.1 to $0.15 \mathrm{ml}$ ) were drawn at $0.17,0.33,0.5,0.67,0.83,1$, $1.5,2,3,5,7.5,10,15,30$, and $60 \mathrm{~min}$ after ${ }^{11} \mathrm{C}$ SA4503 injection and the start of the microPET scan. From these samples, $25 \mu \mathrm{l}$ of whole blood was collected and plasma $(25 \mu \mathrm{l})$ was then obtained by centrifugation of the remaining sample $(5 \mathrm{~min}$ at $13,000 \times \mathrm{g}$ ). Radioactivity in plasma and whole blood was determined using a calibrated gamma counter (CompuGamma CS1282, LKB-Wallac, Turku, Finland). Results are expressed as standardized uptake values (SUV), defined as [(plasma activity concentration $(\mathrm{MBq} / \mathrm{g}) \times$ body weight (g) / injected dose (MBq)]. Rat plasma was assumed to have a specific gravity of $1 \mathrm{~g} / \mathrm{ml}$.

Separate animals were used for analysis of tracer metabolites in plasma. In these rats, five arterial blood samples were collected at 5, 10, 20, 40, and $60 \mathrm{~min}$. Plasma was obtained from these samples by centrifugation $(2 \mathrm{~min}$ at $13,000 \times \mathrm{g}$ ). One volume of plasma was mixed with one volume of a 1:1 mixture of $20 \%$ trichloroacetic acid and acetonitrile. Proteins were precipitated by centrifugation $(2 \mathrm{~min}$ at $13,000 \times g)$. The clear supernatant was injected in a reversed-phase HPLC system to separate parent tracer and metabolites. An Alltima C18 column $(250 \times 10 \mathrm{~mm}, 5 \mu)$ was used; the mobile phase consisted of $100 \mathrm{mM} \mathrm{NaH} \mathrm{PO}_{4} /$ ethanol 55:45 $(v / v)$ at a flow rate of $3 \mathrm{ml} / \mathrm{min}$. The eluate was collected in 20 -s fractions for $12 \mathrm{~min}$, and radioactivity in the fractions was measured using a gamma counter. Retention time of authentic ${ }^{11} \mathrm{C}-\mathrm{SA} 4503$ was 7.5 min whereas two metabolites were eluted at retention

Table 1 Data concerning the experimental animals (body weights, injected doses, group sizes)

\begin{tabular}{|c|c|c|c|}
\hline \multicolumn{4}{|c|}{ Data concerning ${ }^{11} \mathrm{C}$-raclopride scans } \\
\hline Pridopidine dose (mg kg) & Body weight at scan date $(\mathrm{g})$ & ${ }^{11} \mathrm{C}$-raclopride injected (MBq) & Number of animals $(N)$ \\
\hline 0 & $315 \pm 5$ & $37 \pm 4$ & 4 \\
\hline 3 & $339 \pm 19$ & $23 \pm 5$ & 5 \\
\hline 15 & $316 \pm 10$ & $22 \pm 5$ & \\
\hline 60 & $350 \pm 9$ & $25 \pm 1$ & 2 \\
\hline \multicolumn{4}{|c|}{ Data concerning ${ }^{11} \mathrm{C}-\mathrm{SA} 4503$ scans } \\
\hline Pridopidine dose (mg kg) & Body weight at scan date (g) & ${ }^{11} \mathrm{C}-\mathrm{SA} 4503$ injected (MBq) & Number of animals $(N)$ \\
\hline 0 & $354 \pm 28$ & $15 \pm 5$ & 4 \\
\hline 3 & $372 \pm 23$ & $13 \pm 3$ & \\
\hline 15 & $346 \pm 10$ & $11 \pm 4$ & 4 \\
\hline \multicolumn{4}{|c|}{ Data concerning ${ }^{11} \mathrm{C}$-SA4503 metabolite assays } \\
\hline Pridopidine dose (mg kg) & Body weight at scan date (g) & ${ }^{11} \mathrm{C}-\mathrm{SA} 4503$ injected (MBq) & Number of animals $(N)$ \\
\hline 0 & $301 \pm 17$ & $24 \pm 3$ & 2 \\
\hline 3 & $366 \pm 79$ & $33 \pm 6$ & 2 \\
\hline 15 & $336 \pm 28$ & $23 \pm 4$ & 2 \\
\hline
\end{tabular}

Body weights and injected doses are listed as mean \pm SEM 
times of 4.3 and $6.3 \mathrm{~min}$. The areas under the radioactive peaks were calculated, and results were expressed as the fraction of plasma radioactivity representing parent tracer (in \%).

\section{MicroPET scans}

Two rats were scanned in each scan session. They were positioned on heating mats in a microPET Focus 220 system, in transaxial position above each other with their brains in the field of view. Body temperature of the animals was kept close to normal with electronic temperature controllers. Heart rate and oxygen level of the blood during the scan were monitored using pulse oximeters (PulseSense, Nonin). A transmission scan (duration $515 \mathrm{~s}$ ) with a Co-57 point source was first made, in order to correct the subsequently acquired emission data for attenuation and scatter of $511 \mathrm{keV}$ photons. The first rat was injected with tracer $\left({ }^{11} \mathrm{C}\right.$-raclopride or ${ }^{11} \mathrm{C}$-SA4503) simultaneously with the start of the acquisition of emission data by the PET camera, whereas the second animal was injected 16 min later. A list mode protocol was used with a 76-min acquisition time.

Image reconstruction was performed using microPET Manager 2.3.3.6 (Siemens). The PET data were split according to position along the $y$-axis, so that a separate data set was acquired for each animal. The list mode data of the emission scans were reframed in a dynamic sequence of $6 \times 10,4 \times 30$, $2 \times 60,1 \times 120,1 \times 180,4 \times 300$, and $3 \times 600 \mathrm{~s}$ (with an additional 960 -s frame for the rat that was injected first). The data were reconstructed per time frame employing an iterative reconstruction algorithm (OSEM2D with Fourier rebinning, 4 iterations, and 16 subsets). The final datasets consisted of 95 slices with a slice thickness of $0.8 \mathrm{~mm}$ and an in-plane image matrix of $128 \times 128$ pixels. Data sets were corrected for decay, random coincidences, scatter, and attenuation.

\section{Data analysis}

In ${ }^{11} \mathrm{C}$-raclopride scans of the brain, three-dimensional regions of interest (ROIs) were manually drawn over the left and right striatum and cerebellum, using the program ASIPro 6.3.3.0 (Siemens). Each ROI had a standard size of $50 \mu$ l. Timeactivity curves (TACs) were generated for these regions (Fig. 1). The results are expressed as dimensionless standardized uptake values (PET-SUV), defined as [(tissue activity concentration $(\mathrm{MBq} / \mathrm{g}) \times$ body weight $(\mathrm{g}) /$ injected dose $(\mathrm{MBq})]$. Brain tissue was assumed to have a specific gravity of $1 \mathrm{~g} / \mathrm{ml}$.

Time-dependent striatum-to-cerebellum ratios of radioactivity were calculated from these TACs, and a first-order rate equation was fitted to these data (Fig. 2a). Plateau values for the striatum-to-cerebellum ratio were derived from this curve fit. A simplified reference tissue model (Lammertsma and
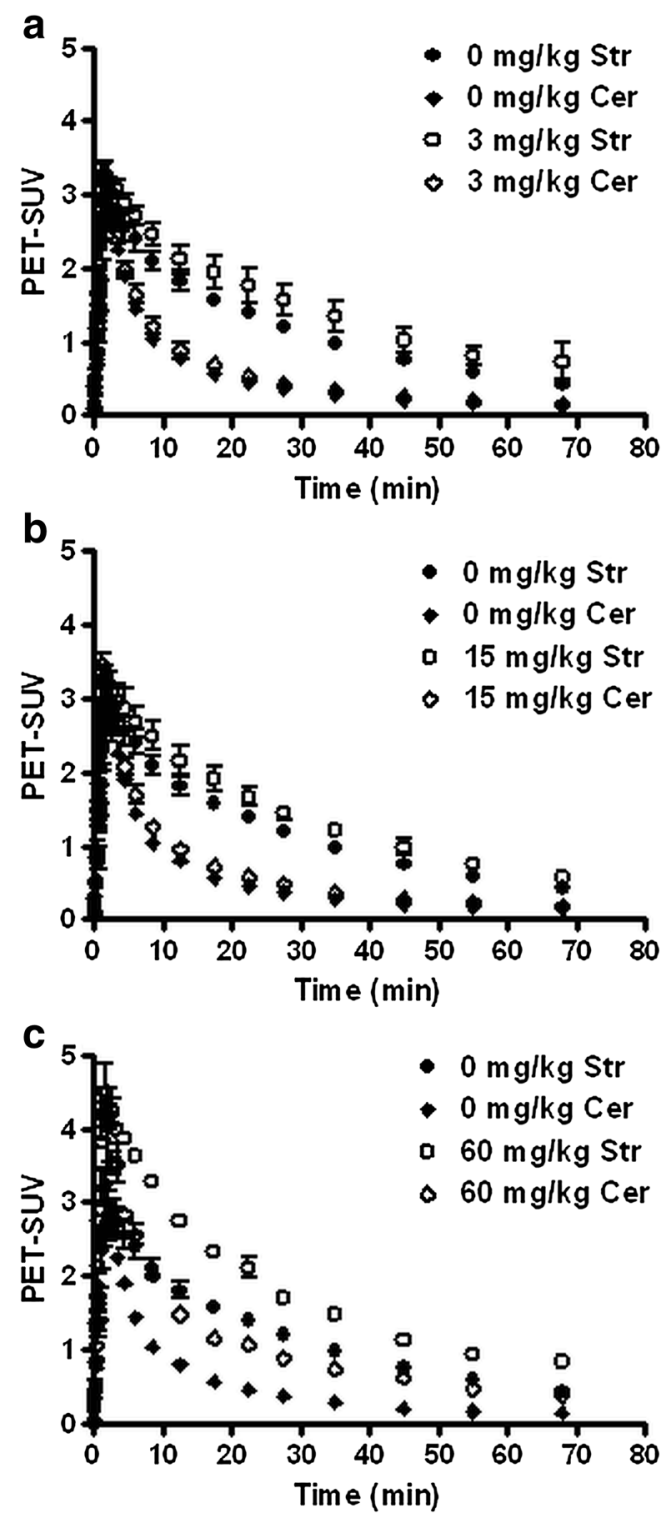

Fig. 1 Time-activity curves of the dopamine $\mathrm{D}_{2}$ receptor ligand ${ }^{11} \mathrm{C}$ raclopride in rat striatum (Str) and cerebellum $(\mathrm{Cer})$ after treatment of animals with 3 (a), 15 (b), or $60 \mathrm{mg} / \mathrm{kg}$ pridopidine (c). Data are plotted as mean \pm SEM

Hume 1996) was also fitted to the striatal TACs, using cerebellum as reference.

PET images for ${ }^{11} \mathrm{C}-\mathrm{SA} 4503$ were co-registered with an MRI template using the program PMOD (PMOD Technologies Ltd, Zürich, Switzerland), and three-dimensional ROIs for individual brain regions were copied from MRI to PET as described previously (Ramakrishnan et al. 2014). Logan graphical analysis was used to calculate regional tracer distribution volumes $\left(V_{\mathrm{T}}\right)$. The starting time of the Logan fit was $20 \mathrm{~min}$. Metabolite-corrected plasma radioactivity data were used as input function, and (uncorrected) whole blood radioactivity served to estimate the contribution of blood to brain radioactivity measured by the PET camera. The plasma timeactivity curve (TAC) of each animal was corrected for 
metabolites using an exponential function obtained from the average metabolite curve of rats which had received the same dose of pridopidine. The PMOD software package was used for curve fitting. A Cunningham-Lassen plot (Lassen et al. 1995; Cunningham et al. 2010) was made to estimate receptor occupancy, as described previously (Ramakrishnan et al. 2014).

\section{Statistics}

Differences between AUCs were examined using the $t$ test. The biodistribution, $V_{\mathrm{T}}$ and $B P$ data were analyzed using ANOVA. A post hoc Bonferroni test was done when applicable. $P$ values $<0.05$ were considered statistically significant.

\section{Results}

\section{${ }^{11} \mathrm{C}$-raclopride kinetics in brain}

The $\mathrm{D}_{2} \mathrm{R}$ ligand ${ }^{11} \mathrm{C}$-raclopride entered the brain within $3 \mathrm{~min}$ and was washed out more rapidly from the reference region (cerebellum) than the target region (striatum) (Fig. 1a). Pretreatment of animals with pridopidine had a dose-dependent effect on the ${ }^{11} \mathrm{C}$ raclopride time-activity curves. At the lowest dose tested $(3 \mathrm{mg} / \mathrm{kg})$, pridopidine appeared to increase tracer uptake in striatum but not in cerebellum (Fig. 1a). When the pridopidine dose was raised to $15 \mathrm{mg} / \mathrm{kg}$, the drug appeared to increase tracer uptake in both striatum and cerebellum to a rather minor extent (Fig. 1b). Administration of $60 \mathrm{mg} / \mathrm{kg}$ pridopidine resulted in a striking increase of the uptake of ${ }^{11} \mathrm{C}$-raclopride in both striatum and cerebellum (Fig. 1c). The relative increase in striatum (compared to uptake at baseline) was smaller than the relative increase in cerebellum.

\section{Target-to-nontarget ratios of ${ }^{11} \mathrm{C}$-raclopride}

In the brain of animals scanned with ${ }^{11} \mathrm{C}$-raclopride, striatum-to-cerebellum ratios of radioactivity rose to a plateau value which was reached after a time interval ranging from 15 to $60 \mathrm{~min}$, depending on the administered pridopidine dose (Fig. 2a). The level of this plateau could be estimated by fitting a first-order rate equation to the PET data. After administration of a low dose of pridopidine $(3 \mathrm{mg} / \mathrm{kg})$, the plateau value appeared to be increased (Fig. 2). A higher pridopidine dose $(15 \mathrm{mg} / \mathrm{kg})$ produced a slight decrease of the level of the plateau (Fig. 2). Particularly, the lowest dose of pridopidine increased the inter-individual variability in the kinetics of ${ }^{11} \mathrm{C}$-raclopride in striata; for this reason,
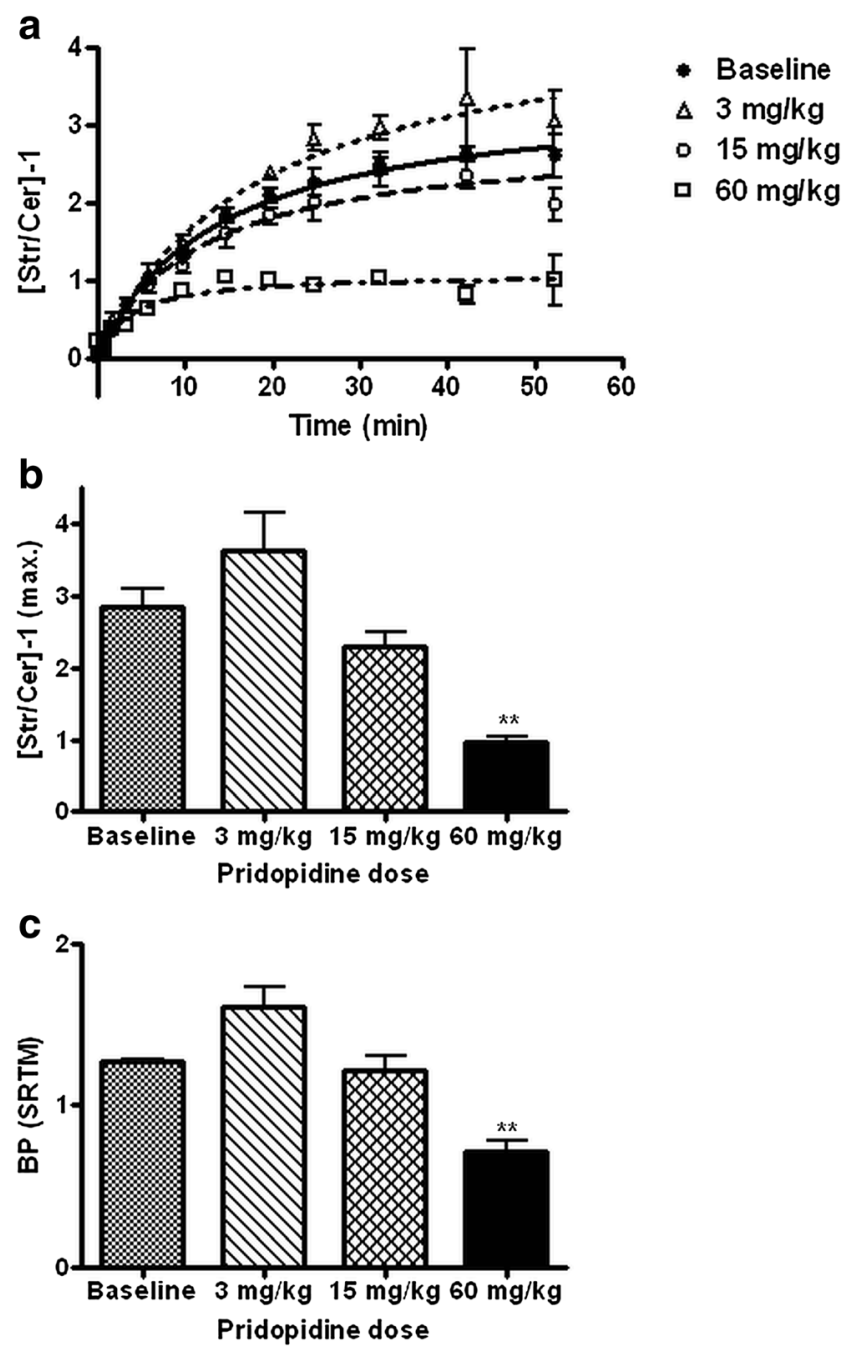

Fig. 2 Time-dependent striatum-to-cerebellum ratios of radioactivity (a), plateau levels of these ratios minus one (b), and binding potential values for ${ }^{11} \mathrm{C}$-raclopride in rat striatum calculated with a simplified reference tissue model (c). Data are plotted as mean \pm SEM

neither the effect of $3 \mathrm{mg} / \mathrm{kg}$ nor that of $15 \mathrm{mg} / \mathrm{kg}$ pridopidine on the level of the plateau was statistically significant (Fig. 2). Administration of $60 \mathrm{mg} / \mathrm{kg}$ pridopidine resulted in a significant decrease of the target-to-nontarget ratio of ${ }^{11} \mathrm{C}$-raclopride (Fig. 2). Target binding of the radioligand (striatum-to-cerebellum ratio at plateau minus one) was reduced from $2.85 \pm$ 0.48 at baseline to $0.96 \pm 0.10$ by $60 \mathrm{mg} / \mathrm{kg}$ pridopidine (mean \pm S.D., $P<0.01$, Fig. $2 b$ ), corresponding to a $\mathrm{D}_{2} \mathrm{R}$ occupancy of $66 \%$.

A simplified reference tissue model (SRTM) could be fitted to the PET data of ${ }^{11} \mathrm{C}$-raclopride, using striatum as the target region and cerebellum as the reference region. Binding potential values calculated with the SRTM demonstrated similar drug-induced changes as striatum-to-cerebellum ratios (Fig. 2c). However, $\mathrm{D}_{2} \mathrm{R}$ occupancy by pridopidine at $60 \mathrm{mg} / \mathrm{kg}$ calculated from the SRTM fit was lower than values 
calculated using the striatum-to-cerebellum ratio (44 vs. $66 \%$, respectively; see Figs. 2c, b).

\section{${ }^{11} \mathrm{C}-\mathrm{SA4503}$ kinetics in brain and plasma}

Uptake of the sigma-1 receptor ligand ${ }^{11} \mathrm{C}-\mathrm{SA} 4503$ in the brain was rapid (Fig. 3a). A maximum was reached within the first $5 \mathrm{~min}$ after tracer injection and was followed by washout. The rate of this washout was increased after pridopidine treatment, and cerebral binding of the ligand was dose-dependently reduced (Fig. 3a). The area under the brain time-activity curve (AUC) was significantly decreased by pridopidine, at both 3 and $15 \mathrm{mg} / \mathrm{kg}(P<0.02$ and $<0.0005$, respectively, Fig. 3b).

Pretreatment of animals with $3 \mathrm{mg} / \mathrm{kg}$ pridopidine had very little impact on the clearance of ${ }^{11} \mathrm{C}$-SA4503-derived radioactivity from plasma (Fig. 4a). However, after treatment of animals with $15 \mathrm{mg} / \mathrm{kg}$ pridopidine, the shape of the plasma curve was altered (Fig. 4b). Compared to untreated controls, plasma levels of radioactivity were initially reduced (during the first 5 min after tracer injection) but subsequently increased (between 10 and $60 \mathrm{~min}$ ). SUV values in Fig. 4 are plotted on a logarithmic $x$-axis in order to avoid that all data points from the initial frames would overlap. Since AUC takes
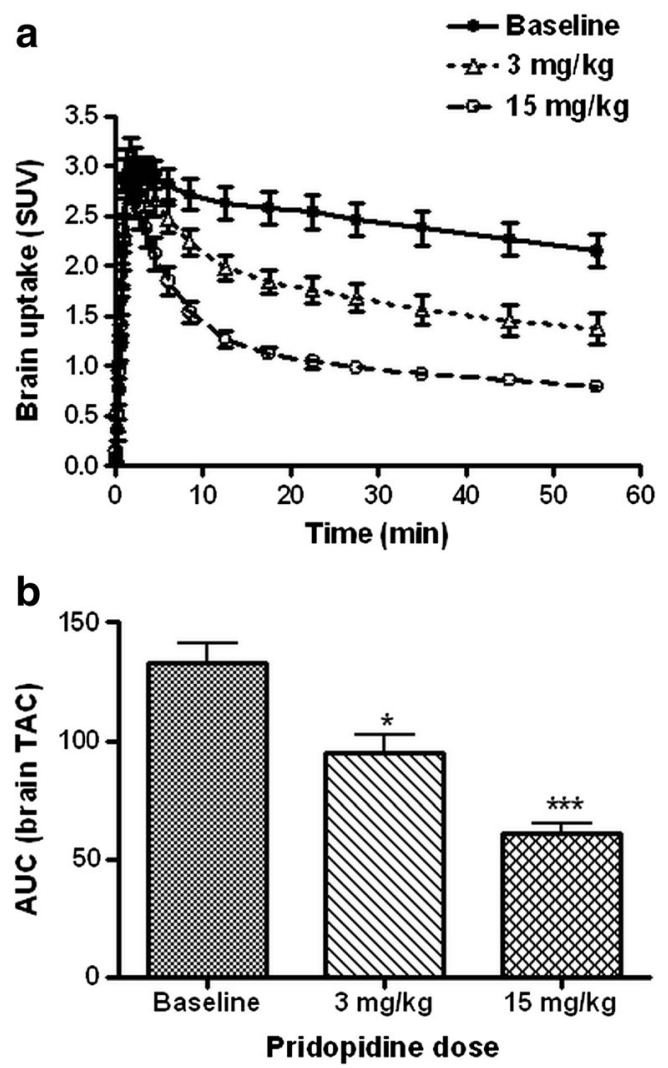

Fig. 3 Time-activity curves of the sigma-1 receptor ligand ${ }^{11}$ C-SA4503 in the entire rat brain (a) and areas under the cerebral time-activity activity curve (b). Data are plotted as mean \pm SEM

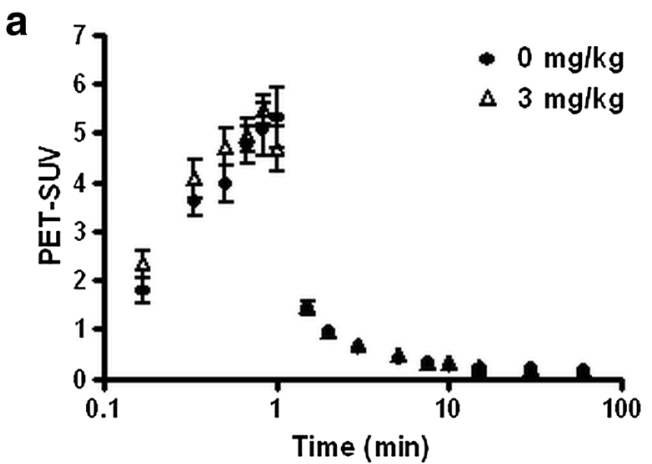

b
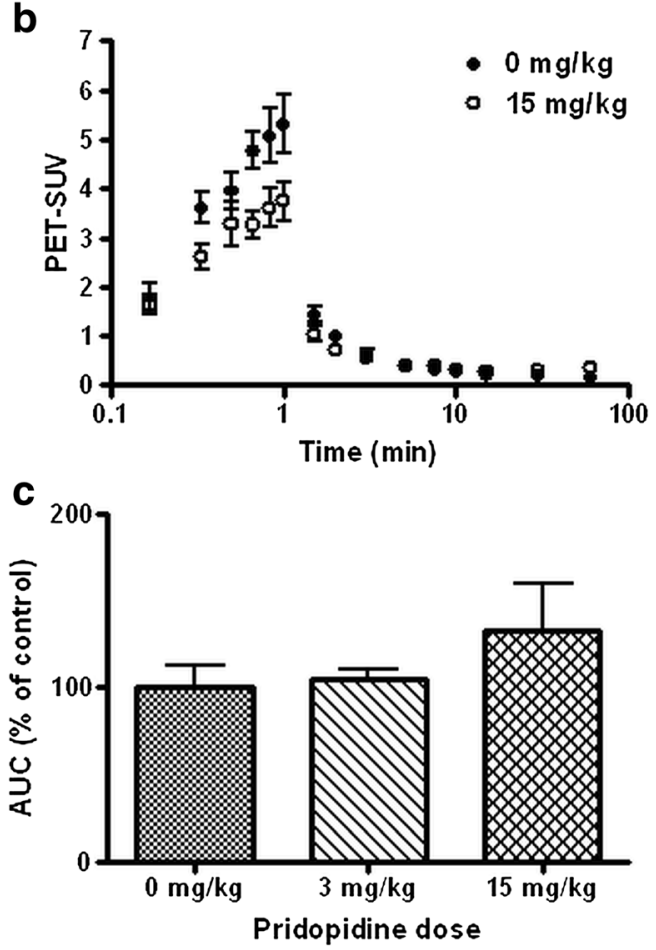

Fig. 4 Time-activity curves of radioactivity in rat plasma after injection of the sigma-1 receptor ligand ${ }^{11} \mathrm{C}-\mathrm{SA} 4503$ (a, b; note logarithmic $x$-axis) and areas under the plasma time-activity curve (c). Data are plotted as mean \pm SEM

frame length into account, a small change of radioactivity in a late frame has more impact on the calculated area than a considerable change in an early frame. The area under the plasma curve tended to be increased after pridopidine treatment, by 5 and $33 \%$ at doses of 3 and $15 \mathrm{mg} / \mathrm{kg}$, respectively (Fig. $4 \mathrm{c}$ ). However, neither of these changes were statistically significant.

\section{Impact of pridopidine on ${ }^{11} \mathrm{C}$-SA4503 metabolism}

Tracer metabolism was dose-dependently accelerated after treatment of rats with various doses of pridopidine (Fig. 5). While $55 \%$ of the parent tracer remained unchanged at $60 \mathrm{~min}$ in saline-treated rats, only 39 and $33 \%$ remained in the 3 and $15 \mathrm{mg} / \mathrm{kg}$ groups. 


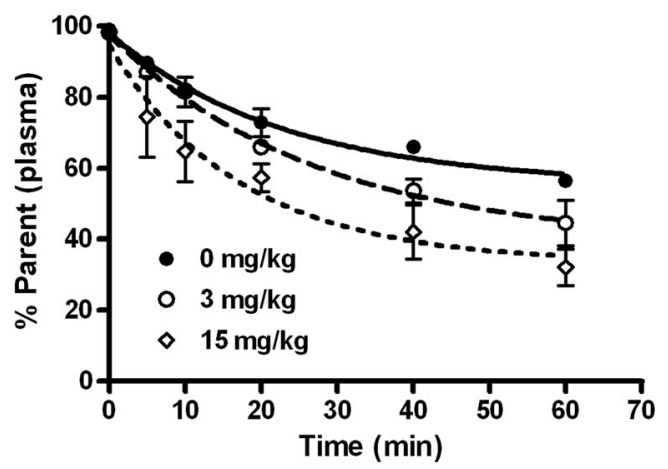

Fig. 5 Fraction of plasma radioactivity representing intact parent compound after injection of ${ }^{11} \mathrm{C}-\mathrm{SA} 4503$. Each data point represents the mean value of two rats

\section{Kinetic analysis and sigma-1 receptor occupancy}

Logan graphical analysis was performed to estimate $V_{\mathrm{T}}$ in the whole brain and in different brain regions. Increasing doses of pridopidine produced a dose-dependent reduction in $V_{\mathrm{T}}$ for all regions investigated (Fig. 6a). The reduction was statistically significant at either dose. The Lassen plot as modified by Cunningham was used to estimate receptor occupancy and $V_{\mathrm{ND}}$ (Fig. 6b). Receptor occupancy was $56.7 \pm 2.3 \%$ at $3 \mathrm{mg} / \mathrm{kg}$ and $84.5 \pm 1.7 \%$ at $15 \mathrm{mg} / \mathrm{kg}$. The $V_{\mathrm{ND}}$ calculated as an average of the two doses administered was 3.99. Since the average whole brain $V_{\mathrm{T}}$ (after metabolite correction) was
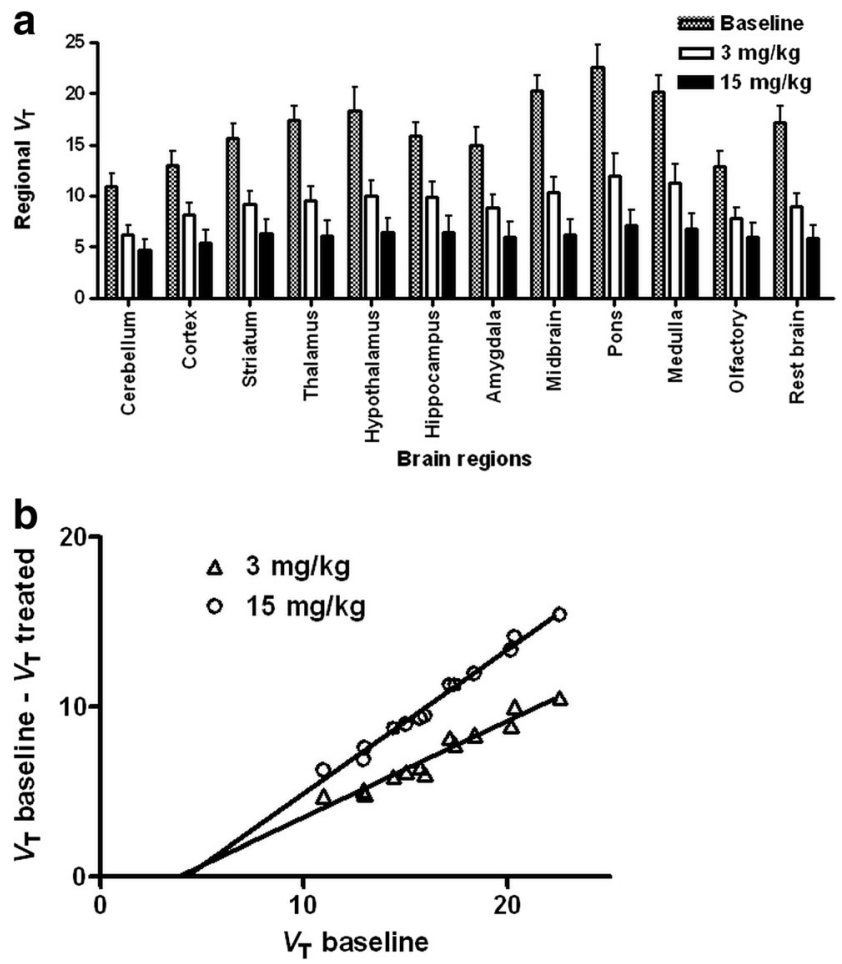

Fig. 6 Total distribution volume $\left(V_{\mathrm{T}}\right)$ of ${ }^{11} \mathrm{C}-\mathrm{SA} 4503$ in different brain regions estimated using Logan graphical analysis (a) and CunninghamLassen plot of sigma-1 receptor occupancy by pridopidine (b). Each data point in the plot represents an individual brain region
14.39 , the specific binding fraction of ${ }^{11} \mathrm{C}-\mathrm{SA} 4503$ in rat brain was $>72 \%$, very similar to the value of $75 \%$ previously reported using the same method in Wistar-Hannover rats (Ramakrishnan et al. 2014).

\section{Biodistribution data}

Biodistribution data for ${ }^{11} \mathrm{C}-\mathrm{SA} 4503$-derived radioactivity are listed in Table 2. Pridopidine reduced radioligand uptake in the brain, large intestine, and kidney. However, the plasma SUV was significantly increased in the $15 \mathrm{mg} / \mathrm{kg}$ dose group. Therefore, tissue-to-plasma ratios of radioactivity provide more information about the drug effect than raw SUV values. Dose-dependent reductions of these ratios were observed in all studied areas of the brain, the kidney, and the spleen. In some other tissues (adrenal gland, bone marrow, large and small intestine, lung), reductions were noted only after administration of the high $(15 \mathrm{mg} / \mathrm{kg})$ dose of pridopidine. Drug effects on tissue-to-plasma ratios in liver and pituitary gland did not reach statistical significance.

\section{Discussion}

The 3 and $15 \mathrm{mg} / \mathrm{kg}$ subcutaneous pridopidine doses used in the present study were chosen since they are at the lower end of the dose range known to produce neurochemical and behavioral effects in rats, e.g., $1.7 \mathrm{mg} / \mathrm{kg}$ increased dopamine release in striatum (Ponten et al. 2010), $7.9 \mathrm{mg} / \mathrm{kg}$ decreased L-DOPA-induced rotational asymmetry in 6hydroxydopamine-hemilesioned rats (Ponten et al. 2013), $10 \mathrm{mg} / \mathrm{kg}$ induced Arc gene expression in frontal cortex (Waters et al. 2014), and $15.9 \mathrm{mg} / \mathrm{kg}$ decreased MK-801- and amphetamine-induced hyperlocomotion and increased locomotor activity in habituated rats (Rung et al. 2008; Ponten et al. 2010).

No significant changes in ${ }^{11} \mathrm{C}$-raclopride binding were observed following treatment with 3 and $15 \mathrm{mg} / \mathrm{kg}$ pridopidine. Curiously however, there was a trend for increased ${ }^{11} \mathrm{C}$ raclopride binding at $3 \mathrm{mg} / \mathrm{kg}$, along with an increase in the variability of radiotracer binding between animals. The mechanisms behind these effects are unclear but could potentially involve sigma-1R-mediated alterations of $\mathrm{D}_{2} \mathrm{R}$ expression or binding properties, since $\mathrm{D}_{2} \mathrm{R}$ and sigma-1 $\mathrm{R}$ have been shown to form heteromers in striatum (Navarro et al. 2013). Based on published ex vivo data (Natesan et al. 2006), we expected to detect substantial $\mathrm{D}_{2} \mathrm{R}$ occupancy at $15 \mathrm{mg} / \mathrm{kg}$. Since we did not observe a significant decrease in ${ }^{11} \mathrm{C}$-raclopride binding at this dose, we evaluated $60 \mathrm{mg} / \mathrm{kg}$ in two additional animals to confirm $\mathrm{D}_{2} \mathrm{R}$ binding by pridopidine using in vivo PET. Indeed, at this elevated dose, a $\mathrm{D}_{2} \mathrm{R}$ occupancy of 66 or $44 \%$ (as determined using the striatum-to-cerebellum ratio or SRTM methods, respectively) was observed. Binding potential (BP) 
Table 2 Biodistribution data of ${ }^{11} \mathrm{C}-\mathrm{SA} 4503$ in the various treatment groups

\begin{tabular}{|c|c|c|c|}
\hline Tissue & Baseline & $3 \mathrm{mg} / \mathrm{kg}$ & $15 \mathrm{mg} / \mathrm{kg}$ \\
\hline \multicolumn{4}{|c|}{ Uptake of radioactivity (SUV values), $80 \mathrm{~min}$ after injection of ${ }^{11} \mathrm{C}-\mathrm{SA} 4503$} \\
\hline Cerebellum & $1.95 \pm 0.12$ & $0.76 \pm 0.17 * * *$ & $0.73 \pm 0.03 * * *$ \\
\hline Cerebral cortex & $1.97 \pm 0.15$ & $1.17 \pm 0.17^{*}$ & $0.87 \pm 0.05^{* *}$ \\
\hline Rest brain & $2.23 \pm 0.31$ & $1.10 \pm 0.05^{*}$ & $0.65 \pm 0.03 *$ \\
\hline Adipose tissue & $0.26 \pm 0.05$ & $0.27 \pm 0.06$ & $0.36 \pm 0.04$ \\
\hline Adrenal gland & $25.7 \pm 3.6$ & $23.0 \pm 4.1$ & $10.7 \pm 4.1$ \\
\hline Bladder & $0.70 \pm 0.10$ & $0.88 \pm 0.38$ & $0.83 \pm 0.22$ \\
\hline Bone & $0.44 \pm 0.14$ & $0.26 \pm 0.03$ & $0.44 \pm 0.05$ \\
\hline Bone marrow & $2.57 \pm 0.47$ & $2.62 \pm 0.67$ & $2.20 \pm 0.77$ \\
\hline Heart & $0.33 \pm 0.04$ & $0.23 \pm 0.01$ & $0.38 \pm 0.02$ \\
\hline Intestine (large) & $1.72 \pm 0.13$ & $1.21 \pm 0.12 *$ & $0.74 \pm 0.08^{* * *}$ \\
\hline Intestine (small) & $2.33 \pm 0.28$ & $1.93 \pm 0.40$ & $1.70 \pm 0.15$ \\
\hline Kidney & $4.19 \pm 0.20$ & $2.10 \pm 0.09 * * *$ & $2.07 \pm 0.15^{* * *}$ \\
\hline Liver & $6.47 \pm 0.63$ & $7.71 \pm 0.89$ & $7.21 \pm 0.83$ \\
\hline Lung & $1.98 \pm 0.18$ & $1.05 \pm 0.06^{*}$ & $1.47 \pm 0.04$ \\
\hline Muscle & $0.15 \pm 0.02$ & $0.13 \pm 0.01$ & $0.22 \pm 0.02 *$ \\
\hline Pancreas & $4.95 \pm 0.74$ & $5.02 \pm 0.64$ & $6.23 \pm 0.53$ \\
\hline Pituitary & $3.24 \pm 0.03$ & $2.13 \pm 0.44$ & $2.75 \pm 0.72$ \\
\hline Plasma & $0.11 \pm 0.02$ & $0.14 \pm 0.02$ & $0.28 \pm 0.02 * * *$ \\
\hline Red blood cells & $0.10 \pm 0.03$ & $0.07 \pm 0.01$ & $0.16 \pm 0.01$ \\
\hline Spleen & $2.62 \pm 0.27$ & $2.03 \pm 0.12$ & $1.99 \pm 0.07$ \\
\hline Submandibular gland & $3.60 \pm 0.18$ & $4.48 \pm 0.64$ & $5.77 \pm 0.39$ \\
\hline Urine & $0.35 \pm 0.16$ & $1.60 \pm 0.87$ & $0.50 \pm 0.09$ \\
\hline \multicolumn{4}{|c|}{ Tissue-to-plasma ratios of radioactivity, $80 \mathrm{~min}$ after injection of ${ }^{11} \mathrm{C}-\mathrm{SA} 4503$} \\
\hline Cerebellum & $20.0 \pm 2.8$ & $5.9 \pm 1.5^{* *}$ & $2.7 \pm 0.3 * *$ \\
\hline Cerebral cortex & $20.1 \pm 2.9$ & $9.0 \pm 1.7 *$ & $3.2 \pm 0.3 * *$ \\
\hline Rest brain & $22.0 \pm 2.1$ & $8.4 \pm 1.3 * * *$ & $2.4 \pm 0.2 * * *$ \\
\hline Adipose tissue & $2.6 \pm 0.5$ & $1.8 \pm 0.2$ & $1.3 \pm 0.1$ \\
\hline Adrenal gland & $186 \pm 13$ & $184 \pm 49$ & $38 \pm 14 * * *$ \\
\hline Bladder & $7.7 \pm 2.0$ & $6.9 \pm 3.4$ & $3.2 \pm 1.0$ \\
\hline Bone & $4.0 \pm 0.8$ & $2.1 \pm 0.4$ & $1.6 \pm 0.2$ \\
\hline Bone marrow & $20.6 \pm 2.6$ & $21.3 \pm 8.1$ & $8.6 \pm 3.4^{*}$ \\
\hline Heart & $3.4 \pm 0.7$ & $1.7 \pm 0.2$ & $1.4 \pm 0.1$ \\
\hline Intestine (large) & $18.5 \pm 4.2$ & $9.5 \pm 2.1$ & $2.8 \pm 0.4^{*}$ \\
\hline Intestine (small) & $25.4 \pm 6.1$ & $13.6 \pm 1.6$ & $6.2 \pm 0.3 *$ \\
\hline Kidney & $44.3 \pm 8.7$ & $16.1 \pm 2.3^{*}$ & $7.6 \pm 0.3^{*}$ \\
\hline Liver & $71.6 \pm 18.7$ & $59.3 \pm 12.4$ & $27.2 \pm 4.7$ \\
\hline Lung & $21.0 \pm 4.7$ & $8.3 \pm 1.6$ & $5.5 \pm 0.5^{*}$ \\
\hline Muscle & $1.7 \pm 0.4$ & $1.0 \pm 0.2$ & $0.8 \pm 0.1$ \\
\hline Pancreas & $52.2 \pm 11.5$ & $36.7 \pm 2.5$ & $23.2 \pm 2.7$ \\
\hline Pituitary & $23.6 \pm 0.5$ & $16.7 \pm 4.6$ & $10.7 \pm 3.4$ \\
\hline Red blood cells & $0.8 \pm 0.1$ & $0.5 \pm 0.1 *$ & $0.6 \pm 0.0^{*}$ \\
\hline Spleen & $26.3 \pm 2.6$ & $16.0 \pm 3.2 *$ & $7.4 \pm 0.7 * *$ \\
\hline Submandibular gland & $38.1 \pm 7.6$ & $32.3 \pm 0.5$ & $21.6 \pm 2.6$ \\
\hline Urine & $4.6 \pm 2.4$ & $13.5 \pm 7.8$ & $1.9 \pm 0.4$ \\
\hline
\end{tabular}

Data are listed as mean \pm SEM. $N=4$ in all groups

$* P<0.05, * * P<0.01, * * * P<0.005$ (compared to baseline value) data calculated from the SRTM fit are probably the most reliable, since data from the ratio method can deviate from the true BP values, depending on the kinetics of tracer clearance from plasma and tissue. Our SRTM data correspond closely to BP values reported earlier by Lammertsma and Hume (1996). Particularly at $60 \mathrm{mg} / \mathrm{kg}$, pridopidine seemed to increase the levels of ${ }^{11} \mathrm{C}$-raclopride in rat plasma, resulting in increased nondisplaceable binding of the tracer throughout the brain (Fig. 1c).

The results of the present study are somewhat divergent from those of Natesan et al. 2006, who observed substantial $\mathrm{D}_{2} \mathrm{R}$ occupancy $(35 \%)$ at $10 \mathrm{mg} / \mathrm{kg}$ and an $\mathrm{ED}_{50}$ of $18.99 \mathrm{mg} / \mathrm{kg}$. The use of different methodology (in vivo PET vs. ex vivo radioligand binding) and/or different strains of rats (Wistar Unilever vs. Sprague-Dawley) may partially explain the differences in the results obtained. Moreover, isoflurane anaesthesia, which may inhibit dopamine release (Westphalen et al. 2013), was used during in vivo PET recordings but not in the previous study. Therefore, the larger pridopidine-induced decreases in ${ }^{3} \mathrm{H}$-raclopride binding observed by Natesan et al. (2006) may have been produced both by increases of dopamine release and by occupancy of $D_{2} R$ by pridopidine. However, other researchers have reported that the sensitivity of ${ }^{3} \mathrm{H}$-raclopride binding to amphetamine-induced dopamine release was not significantly affected by isoflurane (McCormick et al. 2011).

Pridopidine was administered s.c. since this route of administration was used in the occupancy study by Natesan et al. (2006), as well as in the majority of behavioral studies cited in the present work. It could be argued that pridopidine uptake in brain may be submaximal $1 \mathrm{~h}$ after s.c. administration, due to slow redistribution from the injection site, resulting in underestimation of $\mathrm{D}_{2} \mathrm{R}$ occupancy. However, time course data reported by Natesan et al. (2006) suggest that maximal $\mathrm{D}_{2} \mathrm{R}$ occupancy is reached already within $1 \mathrm{~h}$ after s.c. injection and is maintained for $4 \mathrm{~h}$. It could also be argued that different radiotracer affinities may have biased the present results. The affinities of ${ }^{11} \mathrm{C}$-raclopride and ${ }^{11} \mathrm{C}$-SA4503 for their respective targets are not very different $\left(K_{\mathrm{d}} \mathrm{S}\right.$ in rat brain tissue of 1.2 and $4.5 \mathrm{nM}$, respectively; Köhler et al. 1985; Ishiwata et al. 2003). Furthermore, at the tracer doses used in PET, radiotracer affinity should not affect occupancy measurements when the competitor (pridopidine in this case) is present at constant levels (Laruelle 2000). Considering the time course data cited above, the assumption of constant competitor levels seems reasonable.

Human occupancy data for pridopidine have not yet been reported, but a recent ${ }^{11} \mathrm{C}$-raclopride study (Tolboom et al. 2015) examined $D_{2} R$ occupancy by (-)-OSU6162 and observed a 2 to $33 \%$ occupancy in human subjects that received doses ranging from 15 to $90 \mathrm{mg}$ (between 0.14 and $1.25 \mathrm{mg} / \mathrm{kg}$ ). Since the dose-occupancy curve appeared to level off at $40 \%$, the authors suggested that (-)-OSU6162 
selectively occupies a subset of striatal $\mathrm{D}_{2} \mathrm{Rs}$, a property which could potentially account for some of the characteristics of dopamine stabilizers. However, as cautioned by the authors, firm conclusions concerning maximal occupancy could not be drawn since a limited dose range was examined (for safety reasons) and since the number of subjects was small. Ekesbo et al. (1999) reported a $76 \%$ displacement of ${ }^{11} \mathrm{C}$ raclopride by continuous infusion of (-)-OSU6162 $(3 \mathrm{mg} / \mathrm{kg} / \mathrm{h})$ in rhesus monkeys, suggesting that in nonhuman primates, a large fraction of striatal $\mathrm{D}_{2} \mathrm{Rs}$ is accessible to (-)OSU6162, similar to rodents (Natesan et al. 2006). Our microPET data suggest that $\mathrm{D}_{2}$ Rs in rat brain are only occupied by pridopidine at relatively high $(60 \mathrm{mg} / \mathrm{kg})$ doses.

Dopamine stabilizers show some characteristics which are not usually associated with $\mathrm{D}_{2} \mathrm{R}$ ligands, such as pro-cognitive actions in natural forgetting and scopolamine-induced amnesia (Nilsson and Carlsson 2013), neuroprotective effects in in vitro and in vivo models of Huntington's disease (Ruiz et al. 2012; DiPardo et al. 2013), and increased social interaction in the MK-801 rat model of social withdrawal in schizophrenia (Rung et al. 2005). In this context, the substantial occupancy of sigma- $1 \mathrm{R}$ by pridopidine at 3 and $15 \mathrm{mg} / \mathrm{kg}$, as demonstrated in the present study, is of particular interest since sigma-1R ligands have been shown to possess antiamnesic and neuroprotective actions, efficacy against negative symptoms in schizophrenia, and positive modulatory effects on NMDA receptor activity (Maurice and Su 2009; Hayashi et al. 2011; van Waarde et al. 2011). If verified in a patient population, the potentially disease-modifying neuroprotective effects of pridopidine would be highly relevant for the treatment of Huntington's patients. Sigma-1R has generated much attention as a target for neuroprotective treatment, and the sigma-1R agonist PRE-084 was recently demonstrated to alleviate motor impairments and restore dopamine terminal density in 6-hydroxydopamine-lesioned mice, an effect which was not observed in sigma-1R knockout animals (Francardo et al. 2014). Finally, sigma-1R ligands have been reported to attenuate the locomotor effects elicited by methamphetamine (Matsumoto et al. 2008), which could explain the findings reported by Natesan et al. (2006) and Svensson et al. (2009) that the ability of pridopidine to inhibit amphetamine-induced locomotion is more potent than that of (-)-OSU6162 and persists in $\mathrm{D}_{2} \mathrm{R}$ knockout mice.

In conclusion, the present study confirms a selective preference of pridopidine for sigma-1Rs over $\mathrm{D}_{2} \mathrm{Rs}$ and demonstrates that pridopidine, in vivo, occupies a large fraction of sigma-1Rs at the lower end of its behaviorally and neurochemically active dose range, while requiring higher doses to produce significant $\mathrm{D}_{2} \mathrm{R}$ occupancy. Our findings warrant further investigation of the role of sigma-1 receptors in the behavioral and neuroprotective effects of dopamine stabilizers and of pridopidine in particular. However, the pharmacological characterization of sigma-1R-mediated effects may prove challenging since the classification of sigma ligands into agonists and antagonists remains tentative. The functional effects of sigma-1R ligands in different cellular and subcellular contexts may even depend on the heteromeric partners of sigma-1Rs. Furthermore, whereas several prescribed CNS drugs are known to significantly occupy sigma-1R at therapeutic doses, the relevance of this occupancy for treatment response has not yet been convincingly demonstrated. Future experiments employing sigma-1R knockout animals, rather than a pharmacological blocking approach, may yield more easily interpretable data.

Acknowledgments The present study was supported by grants from IMBRAIN (FP7-REGPOT-2012-CT2012-316137-IMBRAIN; DM). $\mathrm{KS}$ is a recipient of postdoctoral fellowships from the Swedish Society for Medical Research and the Swedish Brain Foundation.

Conflict of interest There are no circumstances that could be perceived as a potential conflict of interest.

Open Access This article is distributed under the terms of the Creative Commons Attribution 4.0 International License (http:// creativecommons.org/licenses/by/4.0/), which permits unrestricted use, distribution, and reproduction in any medium, provided you give appropriate credit to the original author(s) and the source, provide a link to the Creative Commons license, and indicate if changes were made.

\section{References}

Cunningham VJ, Rabiner EA, Slifstein M, Laruelle M, Gunn RN (2010) Measuring drug occupancy in the absence of a reference region: the Lassen plot re-visited. J Cereb Blood Flow Metab 30:46-50

de Yebenes JG, Landwehrmeyer B, Squitieri F, Reilmann R, Rosser A, Barker RA, Saft C, Magnet MK, Sword A, Rembratt A, Tedroff J, MermaiHD study investigators (2011) Pridopidine for the treatment of motor function in patients with Huntington's disease (MermaiHD): a phase 3, randomised, double-blind, placebocontrolled trial. Lancet Neurol 10:1049-1057

DiPardo A, Maglione V, Favellato MG, Amico E, Squitieri F (2013) Potential neuroprotective effects of pridopidine in Huntington's disease [abstract]. Mov Disord 28(Suppl 1):768

Dyhring T, Nielsen EØ, Sonesson C, Pettersson F, Karlsson J, Svensson P, Christophersen P, Waters N (2010) The dopaminergic stabilizers pridopidine (ACR16) and (-)-OSU6162 display dopamine $\mathrm{D}_{2}$ receptor antagonism and fast receptor dissociation properties. Eur $\mathrm{J}$ Pharmacol 628:19-26

Ekesbo A, Torstenson R, Hartvig P, Carlsson A, Sonesson C, Waters N, Tedroff J, Långström B (1999) Effects of the substituted (S)-3phenylpiperidine (-)-OSU6162 on PET measurements of $\left[{ }^{11} \mathrm{C}\right] \mathrm{SCH} 23390$ and $\left[{ }^{11} \mathrm{C}\right]$ raclopride binding in primate brains. Neuropharmacology 38:331-338

Farde L, Pauli S, Hall H, Eriksson L, Halldin C, Högberg T, Nilsson L, Sjögren I, Stone-Elander S (1988) Stereoselective binding of ${ }^{11} \mathrm{C}$ raclopride in living human brain - a search for extrastriatal central $\mathrm{D}_{2}$-dopamine receptors by PET. Psychopharmacology 94:471-478

Fontanilla D, Johannessen M, Hajipour AR, Cozzi NV, Jackson MB, Ruoho AE (2009) The hallucinogen N, N-dimethyltryptamine (DMT) is an endogenous sigma-1 receptor regulator. Science 323: 934-937 
Francardo V, Bez F, Wieloch T, Nissbrandt H, Ruscher K, Cenci MA (2014) Pharmacological stimulation of sigma-1 receptors has neurorestorative effects in experimental parkinsonism. Brain 137: 1998-2014

Guitart X, Codony X, Monroy X (2004) Sigma receptors: biology and therapeutic potential. Psychopharmacology 174:301-319

Hayashi T, Tsai SY, Mori T, Fujimoto M, Su TP (2011) Targeting ligandoperated chaperone sigma-1 receptors in the treatment of neuropsychiatric disorders. Expert Opin Ther Targets 15:557-577

Ishiwata K, Kobayashi T, Kawamura K, Matsuno K (2003) Age-related changes of the binding of [3H]SA4503 to sigma1 receptors in the rat brain. Ann Nucl Med 17:73-77

Kara E, Lin H, Svensson K, Johansson AM, Strange PG (2010) Analysis of the actions of the novel dopamine receptor-directed compounds (S)-OSU6162 and ACR16 at the D2 dopamine receptor. Br J Pharmacol 161:1343-1350

Kawamura K, Elsinga PH, Kobayashi T, Ishii S, Wang WF, Matsuno K, Vaalburg W, Ishiwata $\mathrm{K}$ (2003) Synthesis and evaluation of ${ }^{11} \mathrm{C}$ - and ${ }^{18}$ F-labeled 1-[2-(4-alkoxy-3-methoxyphenyl)ethyl]-4-(3phenylpropyl)piperazines as sigma receptor ligands for positron emission tomography studies. Nucl Med Biol 30:273-284

Kieburtz K, McGarry A, McDermott M, Kayson E, Harrison M, Marder K, Walker F, Corey-Bloom J, Goldstein J, Hyson C, Megans J, Huntington Study Group HART Investigators (2013) A randomized, double-blind, placebo-controlled trial of pridopidine in Huntington's disease. Mov Disord 28:1407-1415

Köhler C, Hall H, Ogren SO, Gawell L (1985) Specific in vitro and in vivo binding of $3 \mathrm{H}$-raclopride. A potent substituted benzamide drug with high affinity for dopamine D-2 receptors in the rat brain. Biochem Pharmacol 34:2251-2259

Lammertsma AA, Hume SP (1996) Simplified reference tissue model for PET receptor studies. Neuroimage 4:153-158

Laruelle M (2000) Imaging synaptic neurotransmission with in vivo binding competition techniques: a critical review. J Cereb Blood Flow Metab 20:423-451

Lassen NA, Bartenstein PA, Lammertsma AA, Prevett MC, Turton DR, Luthra SK, Osman S, Bloomfield PM, Jones T, Patsalos PN (1995) Benzodiazepine receptor quantification in vivo in humans using $\left[{ }^{11} \mathrm{C}\right]$ flumazenil and PET: application of the steady-state principle. J Cereb Blood Flow Metab 15:152-165

Matsumoto RR, Shaikh J, Wilson LL, Vedam S, Coop A (2008) Attenuation of methamphetamine-induced effects through the antagonism of sigma receptors: evidence from in vivo and in vitro studies. Eur Neuropsychopharmacol 18:871-881

Maurice T, Su TP (2009) The pharmacology of sigma-1 receptors. Pharmacol Ther 124:195-206

McCormick PN, Ginovart N, Wilson AA (2011) Isoflurane anaesthesia differentially affects the amphetamine sensitivity of agonist and antagonist $D_{2} / D_{3}$ positron emission tomography radiotracers: implications for in vivo imaging of dopamine release. Mol Imaging Biol 13: 737-746

Natesan S, Svensson KA, Reckless GE, Nobrega JN, Barlow KB, Johansson AM, Kapur S (2006) The dopamine stabilizers (S)-(-)(3-methanesulfonyl-phenyl)-1-propyl-piperidine [(-)-OSU6162] and 4-(3-methanesulfonylphenyl)-1-propyl-piperidine (ACR16) show high in vivo $\mathrm{D}_{2}$ receptor occupancy, antipsychotic-like effica$\mathrm{cy}$, and low potential for motor side effects in the rat. J Pharmacol Exp Ther 318:810-818

Navarro G, Moreno E, Aymerich M, Marcellino D, McCormick PJ, Mallol J, Cortés A, Casadó V, Canela EI, Ortiz J, Fuxe K, Lluís C, Ferré S, Franco R (2010) Direct involvement of sigma-1 receptors in the dopamine D1 receptor-mediated effects of cocaine. Proc Natl Acad Sci U S A 107:18676-18681

Navarro G, Moreno E, Bonaventura J, Brugarolas M, Farré D, Aguinaga D, Mallol J, Cortés A, Casadó V, Lluís C, Ferre S, Franco R, Canela
E, McCormick PJ (2013) Cocaine inhibits dopamine D2 receptor signaling via sigma-1-D2 receptor heteromers. PLoS One 8, e61245

Nilsson MK, Carlsson ML (2013) The monoaminergic stabilizer (-)OSU6162 reverses delay-dependent natural forgetting and improves memory impairment induced by scopolamine in mice. Neuropharmacology 75:399-406

Pettersson F, Ponten H, Waters N, Waters S, Sonesson C (2010) Synthesis and evaluation of a set of 4-phenylpiperidines and 4-phenylpiperazines as $\mathrm{D}_{2}$ receptor ligands and the discovery of the dopaminergic stabilizer 4-[3-(methylsulfonyl)phenyl]-1-propylpiperidine (Huntexil, Pridopidine, ACR16). J Med Chem 53:2510-2520

Ponten H, Kullingsjö J, Lagerkvist S, Martin P, Pettersson F, Sonesson C, Waters S, Waters N (2010) In vivo pharmacology of the dopaminergic stabilizer pridopidine. Eur J Pharmacol 644:88-95

Ponten H, Kullingsjö J, Sonesson C, Waters S, Waters N, Tedroff J (2013) The dopaminergic stabilizer pridopidine decreases expression of $\mathrm{L}$ DOPA-induced locomotor sensitisation in the rat unilateral 6OHDA model. Eur J Pharmacol 698:278-285

Ramakrishnan NK, Visser AK, Schepers M, Luurtsema G, Nyakas CJ, Elsinga PH, Ishiwata K, Dierckx RA, van Waarde A (2014) Dosedependent sigma-1 receptor occupancy by donepezil in rat brain can be assessed with ${ }^{11} \mathrm{C}-\mathrm{SA} 4503$ and microPET. Psychopharmacology 231:3997-4006

Ruiz C, Casarejos MJ, Rubio I, Gines S, Puigdellivol M, Alberch J, Mena MA, de Yebenes JG (2012) The dopaminergic stabilizer, (-)OSU6162, rescues striatal neurons with normal and expanded polyglutamine chains in huntingtin protein from exposure to free radicals and mitochondrial toxins. Brain Res 1459:100-112

Rung JP, Carlsson A, Markinhuhta KR, Carlsson ML (2005) The dopaminergic stabilizers (-)-OSU6162 and ACR16 reverse (+)-MK-801induced social withdrawal in rats. Prog Neuropsychopharmacol Biol Psychiatry 29:833-839

Rung JP, Rung E, Helgeson L, Johansson AM, Svensson K, Carlsson A, Carlsson ML (2008) Effects of (-)-OSU6162 and ACR16 on motor activity in rats, indicating a unique mechanism of dopaminergic stabilization. J Neural Transm 115:899-908

Sahlholm K, Århem P, Fuxe K, Marcellino D (2013) The dopamine stabilizers ACR16 and (-)-OSU6162 display nanomolar affinities at the $\sigma-1$ receptor. Mol Psychiatry 18:12-14

Sahlholm K, Marcellino D, Nilsson J, Ögren SO, Fuxe K, Århem P (2014) Typical and atypical antipsychotics do not differ markedly in their reversibility of antagonism of the dopamine $\mathrm{D}_{2}$ receptor. Int $\mathrm{J}$ Neuropsychopharmacol 17:149-155

Seeman P, Tokita K, Matsumoto M, Matsuo A, Sasamata M, Miyata K (2009) The dopaminergic stabilizer ASP2314/ACR16 selectively interacts with $\mathrm{D}_{2}($ High) receptors. Synapse 63:930-934

Svensson KA, Falcone JF, Johansson AM, Perry KW, Fell MJ (2009) The actions of the dopamine stabilizer ACR16, but not (-)-OSU6162, in behavioral and neurochemical assays are not dependent on the presence of functional dopamine D2 receptors. In: 39th Annual Meeting, Society for Neuroscience, Chicago, October 2009

Tolboom N, Berendse HW, Leysen JE, Yaqub M, van Berckel BN, Schuit RC, Ponsen MM, Bakker E, Hoetjes NJ, Windhorst AD, Carlsson ML, Lammertsma AA, Carlsson A (2015) The dopamine stabilizer (-)-OSU6162 occupies a subpopulation of striatal dopamine $\mathrm{D}_{2} / \mathrm{D}_{3}$ receptors: an $\left[{ }^{11} \mathrm{C}\right]$ raclopride PET study in healthy human subjects. Neuropsychopharmacology 40:472-479

van Waarde A, Ramakrishnan NK, Rybczynska AA, Elsinga PH, Ishiwata K, Nijholt IM, Luiten PG, Dierckx RA (2011) The cholinergic system, sigma-1 receptors and cognition. Behav Brain Res 221:543-554

Visser AK, De Vries EF, Ramakrishnan NK, Willemsen AT, Bosker FJ, den Boer JA, Dierckx RA, van Waarde A (2013) Analysis of 5$\mathrm{HT}_{2 \mathrm{~A}}$ receptor binding with $\left[{ }^{11} \mathrm{C}\right] \mathrm{MDL} 100907$ in rats: optimization of kinetic modeling. Mol Imaging Biol 15:730-738 
Waters S, Ponten H, Eding M, Svanberg B, Keamer D, Waters N (2014) The dopaminergic stabilizers pridopidine and ordopidine enhance cortico-striatal Arc gene expression. J Neural Transm 121:1337-1347
Westphalen RI, Desai KM, Hemmings HC (2013) Presynaptic inhibition of the release of multiple major central nervous system neurotransmitter types by the inhaled anaesthetic isoflurane. Br J Anaesth 110: $592-599$ 